L. ZHANG, D. LIN, X. SUN, U. CURTH, C. DROSTEN, L. SAUERHERING, S. BECKER,

K. ROX, R. HILGENFELD* (UNIVERSITY OF LÜBECK, GERMANY)

Crystal Structure of SARS-CoV-2 Main Protease Provides a Basis for Design of Improved $\alpha$-Ketoamide Inhibitors

Science 2020, 368, 409-412.

\section{$\alpha$-Ketoamide Inhibitors of SARS-CoV-2 Main Protease}<smiles>NC(CC1CC1)C(=O)O</smiles>

1. $\mathrm{NaNO}_{2}, \mathrm{H}_{2} \mathrm{SO}_{4}, \mathrm{H}_{2} \mathrm{O}$ 2. $\mathrm{SOCl}_{2}, \mathrm{MeOH}$ 3. $\mathrm{Tf}_{2} \mathrm{O}, 2,6$-lutidine<smiles>COC(=O)C(O)CC1CC1</smiles><smiles></smiles><smiles>COC(=O)C(N)CC1CCNC1=O</smiles>

1. $\mathrm{LiOH}, \mathrm{MeOH}, \mathrm{H}_{2} \mathrm{O}$<smiles>COC(=O)C(CC1CCNC1=O)NC(=O)[C@@H](CC1CC1)n1cccc(NC(C)(C)C)c1=O</smiles>

\section{Category}

Chemistry in

Medicine and

Biology

Key words

SARS-CoV-2

COVID-19

$\alpha$-ketoamides

main protease

$\left(\mathrm{M}^{\mathrm{pro}}\right)$ 2. $\mathrm{HOBt}, \mathrm{EDCl}, \mathbf{B}$

\section{$\mathrm{NaH}, \mathbf{A}$}<smiles>COC(=O)[C@H](CC1CC1)n1cccc(NC(=O)OCc2ccccc2)c1=O</smiles>

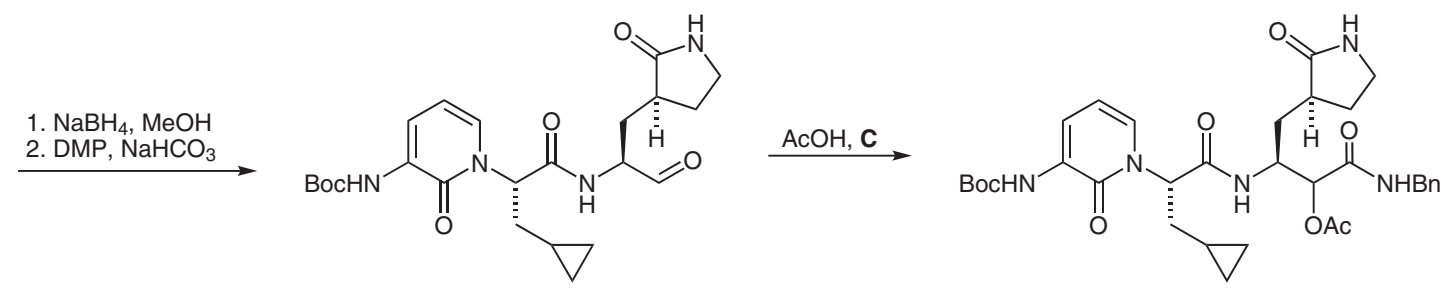<smiles>CC(C)NC(=O)c1cccn(C(CC2CC2)C(=O)Nc2ccccc2)c1=O</smiles>

Significance: SARS-CoV-2 is the virus responsible for the coronavirus disease 2019 (COVID-19) pandemic. Potent, broad-spectrum $\alpha$-ketoamide inhibitors of the main protease $\left(\mathrm{M}^{\mathrm{pro}}\right)$ of betacoronaviruses and alphacoronaviruses were recently reported by Hilgenfeld and co-workers (J. Med. Chem. 2020, DOI: 10.1021/acs.jmedchem.9b01828). $\mathrm{X}$-ray crystallography and structure-based design led to the discovery of submicromolar $\alpha$-ketoamide inhibitor 13b, which has now been developed specifically against SARS-CoV- $2 \mathrm{M}^{\mathrm{pro}}$ to shut down the processing of polyproteins translated from viral RNA.
Comment: Starting from commercially available (R)-2-amino-3-cyclopropylpropanoic acid, Boc-protected pyridone $\mathbf{D}$ is synthesized in four steps. $\gamma$ Lactam B, a proxy for glutamine, is made using an asymmetric dianionic cyanomethylation of $\mathrm{N}$-BocL-(+)-glutamic acid dimethyl ester (Q. Tian et al. Tetrahedron Lett. 2001, 42, 6807) and is coupled to the hydrolysis product of $\mathbf{D}$. Five additional transformations yield 13b, which inhibits SARS-CoV-2 $\mathrm{M}^{\text {Pro }}$ with $\mathrm{IC}_{50}=0.67 \pm 0.18 \mu \mathrm{M}$ and displays promising lung tropism and inhalation tolerance in mice. 